\title{
Mā te rongo ka mohio: Māori Pā Wars and Kaupapa Māori Methodology at the Interface of Video Games
}

\section{Huni Mancini}

Keywords: \# Video games \# Te reo Māori \# Māori design \# Game design \# Indigenous games \# Digital technology \# New media

This essay reviews Māori Pā Wars (2017), a te reo Māori mobile game developed for mobile devices by independent Māori-led video game company Metia Interactive. Through consideration of the historical struggle for cultural and te reo Māori revitalisation, this essay discusses the use of kaupapa Māori methodology to activate mātauranga Māori through gameplay. Situated within a wider global shift towards 'indie' game development and more pertinently 'Indigenous game development,' Māori Pā Wars is one of the first games to bring kaupapa Māori methodology to the interface of video game technology. Through analysis of game development methodology, mechanics, game design and the ubiquitous mobile medium, this essay outlines the ways Mãori Pā Wars challenges a 'literature of dominance.' It concludes that the game borrows from remix and convergence cultures inherent to indie game development, thereby reflecting the way Māori technologies, social and political systems continue to adapt to a changing technological landscape. 


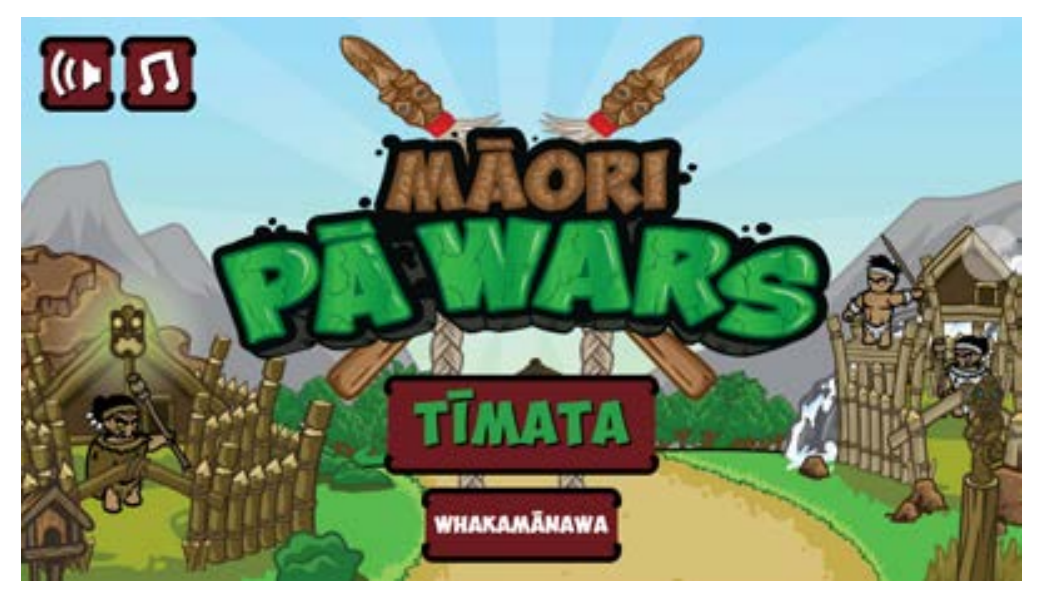

\section{INTRODUCTION}

Video games are everywhere, from the very simple and highly addictive like Candy Crush to the more complex and immersive open worlds of Minecraft and Counter Strike. Defined as interactive media developed for console, computer and mobile devices, video games come in a variety of genres. 'Indigenous games' are those made by a developer or team of developers with Indigenous heritage and use game design, mechanics and methodology to draw on their heritage. Rather than a genre in themselves, Indigenous games are often classified under 'Serious' and 'World' games categories. More recently the term 'Kaupapa Māori games' describes efforts to reinvigorate links to mātauranga Māori (Māori knowledge) and te reo Māori (Māori language) through the digital interactivity of games. Among the first kaupapa Māori video games, Māori Pā Wars demonstrates te reo Māori learning at the interface of virtual technology that combines play and the everyday., 2

Kaupapa Māori is both a theoretical framework and praxis rooted in tikanga Māori, the set of beliefs associated with Māori practices and procedures established by whakapapa (ancestors) over time. ${ }^{3,4}$ More than simply legitimating the Māori way of doing things, kaupapa Māori establishes the conditions which allow Māori to assert greater cultural, political, social, emotional and spiritual control over their lives. ${ }^{5}$ Stemming from The Treaty of Waitangi / Te Tiriti o Waitangi, ${ }^{6}$ rights to sovereignty and ownership continue to be a source of struggle for Māori. However some progress has been made under direction of The Waitangi Tribunal. Established under The Treaty of Waitangi Act 1975 the Tribunal addressed a number of inquiries into Māori claims alleging breaches of the principles of the Treaty by the Crown dating back to 1840.7 One such claim known as 'WAI 262' advocated greater Māori control of intellectual and cultural property rights. ${ }^{8,} 9$ Nevertheless, mainstream attitudes towards Māori throughout the $20^{\text {th }}$ century remained overwhelmingly negative with media reflecting popular assumptions that Māori did not fit into the modern agenda of $\mathrm{New}$ Zealand, often resulting in harmful, essentialising images. ${ }^{10,11}$

The discussion of kaupapa Māori game development reveals ongoing struggles for Māori to assert intellectual and property rights. Central to this conversation is the ongoing appropriation of Indigenous cultures by big game studios which use Indigenous motifs, language and narratives without the consent of the communities they belong to. Occurring within exotic fantasy and 'open-world' military genres, these games reinforce the "literature of dominance," a term used by game developer and academic Dr Elizabeth LaPensée (Anishinaabe/Métis) to describe Western efforts to essentialise Indigenous peoples within a 'traditional vs. modern' binary. ${ }^{12}$ Academic Linda Tuhiwai Smith writes, "At the heart of such a view of authenticity is a belief that indigenous cultures cannot change, cannot recreate themselves and still claim to be indigenous." ${ }^{\prime 13}$ This 'literature of dominance' within the domain of video games enhances the view that Indigenous peoples are static, relics of the past. The immersion of video games suggests this harmful narrative can become entrenched in players over time.

Indigenous game development is situated within a wider global surge of independent game development, a movement that is notorious for pushing boundaries and deconstructing narratives of dominance. This is famously exemplified by the 2014 \#GamerGate controversy that surrounded indie developer Zoë Quinn and her game Depression Quest (2013). Quinn was subjected to extensive harassment resulting in widespread recognition of sexism in gaming. ${ }^{14,15}$ LaPensée was also recently targeted for abuse after being labeled an 'ecoterrorist' by Minnesota state representatives for her game Thunderbird Strike (2017). ${ }^{16}$ Yet the benefit of Indigenous development exceeds those harmful narratives. LaPensée's games Gathering Native Foods (2014), Honour Water (2016) and We Sing For Healing (2015) activate Anishinaabe worldviews through gameplay that expresses nonlinear journeying patterned after Anishinaabe storytelling. ${ }^{17}$ The commercially successful Iñupiat game Never Alone / Kisima Injitchuna (2014) released by Cook Inlet Tribal Council is also notable for the use of Indigenous methodology and game design. 
This essay focuses on aspects of game design in Māori Pā Wars developed from a kaupapa Māori perspective, and considers how game mechanics are used to reclaim use of te reo Māori. The first section speaks to kaupapa Māori game development methodology, while the second looks at iwi warfare and the strategy mechanic. The third section discusses the te reo Māori to English user interface. The last two sections consider Ngā Atua and tipua character design, and discuss the advantages of mobile technology.

The methodology for this essay draws on the author's audio recordings of two symposia held by New Zealand Game Developers Association (NZGDA) titled 'Indigenous Representation in Games' (2017) and 'Māori Games' (2018), which on both occasions were attended in person. These symposia were free, open to the public and advertised online. Maru Nihoniho, Director of Metia Interactive, spoke on the panel at both symposiums, and the audio from these hourlong discussions were recorded on mobile phone by the author and subsequently transcribed. The conclusions drawn in this essay are the result of the author's own analysis based on gameplay, attendance of the symposiums and research, including academic research conducted as part of the author's Masters qualification. The author would like to acknowledge and thank all of the First Nations tribal communities discussed in this essay. The title of this essay, 'Mā te rongo ka mohio' meaning 'Through perception comes awareness,' is borrowed from a Māori proverb highlighted by graphic artist Zak Waipara. ${ }^{18}$ Specia acknowledgements are extended towards Maru Nihoniho, Dr Elizabeth LaPensée and Eric Rangi Hillman for their contributions to this area of research. Mālō 'aupito.

\section{KAUPAPA MĀORI GAME DEVELOPMENT METHODOLOGY}

Maru Nihoniho (Te Whānau-ā-Apanui, Ngāti Porou, Ngāi Tahu) is the founder and director of Metia Interactive whose games includes Cube (2007), released by Playstation Portable and Sparx (2009), made in conjunction with The University of Auckland for youth diagnosed with mild depression. Nihoniho's concerns for turning Māori representation from weakness to strength is reflected in 14 years of game development. Working from a kaupapa Māori framework is central to her practice as it safeguards the knowledge she shares in games.
She explains in one of the NZGDA panel discussions,

Being Maori and working with this content I have to be careful on how I use it and portray it. So I try not to make mistakes myself, and I do my best to talk with elders or people who are quite knowledgeable in different areas. ${ }^{19}$

While developing Māori Pā Wars (MPW) Nihoniho consulted with Māori to ensure correct representation of mātauranga Māori (Māori knowledge). Rather than consulting with kaumatua (elders) she sought advice from professionals with specialised knowledge and skills, such as Bradley Walker (Te Whānau-ā-Apanui, Te Whakatōhea) who is Managing Director at Adrenalin Group, and te reo Māori author Scotty Morrison (Ngāti Whakaue) ${ }^{20}$ Nihoniho says a degree of 'creative license' is needed to find the right balance between delivering mātauranga Māori on a fun and engaging platform, and upholding tikanga Māori. ${ }^{21,22}$ Ongoing appropriation of Indigenous cultures motivates a need to control access to mātauranga Māori in this domain. Academic Dr Dean Mahuta (Ngāti Mahuta) has discussed the importance for Māori to start occupying game development, referencing games The Mark of Kri (2002) and Brink (2011) for their use of tā moko designs, Māori names and terms like 'Rongo,' 'kirituhi' and 'taiaha,' without including any Māori in the process. ${ }^{23}$ Scholars have also recorded a number of games using the appropriation aesthetic, including Far Cry 4 (2014), Crysis (2007), Dead Island (2011), Custer's Revenge (1982), Turok: Dinosaur Hunter (1998) and Assassin's Creed III (2012). ${ }^{24,25}$

To counteract the "literature of dominance" Dr Elizabeth LaPensée advocates for 'Reciprocal development methodology', a process of game development that includes a genuine community of collaborators. This methodology ensures meaningful contribution to games with Indigenous content while also supporting social and/ or economic renewal for those communities. ${ }^{26,27}$ The Iñupiat game Never Alone/Kisima Innitchuna (2014) is an example of this method. Led by Cook Inlet Tribal Council (CITC) in collaboration with Iñupiat community and storytellers, the game drawing out a range of Iñupiat voices to tell the traditional story of Kunuuksaayuka (endless blizzard tale). Amy Fredeen of CITC explained at one NZGDA panel discussion, "We knew if we did it wrong, we would be dishonouring our elders and our ancestors, and then giving our youth the wrong perspective and wisdom to bring forward."28 


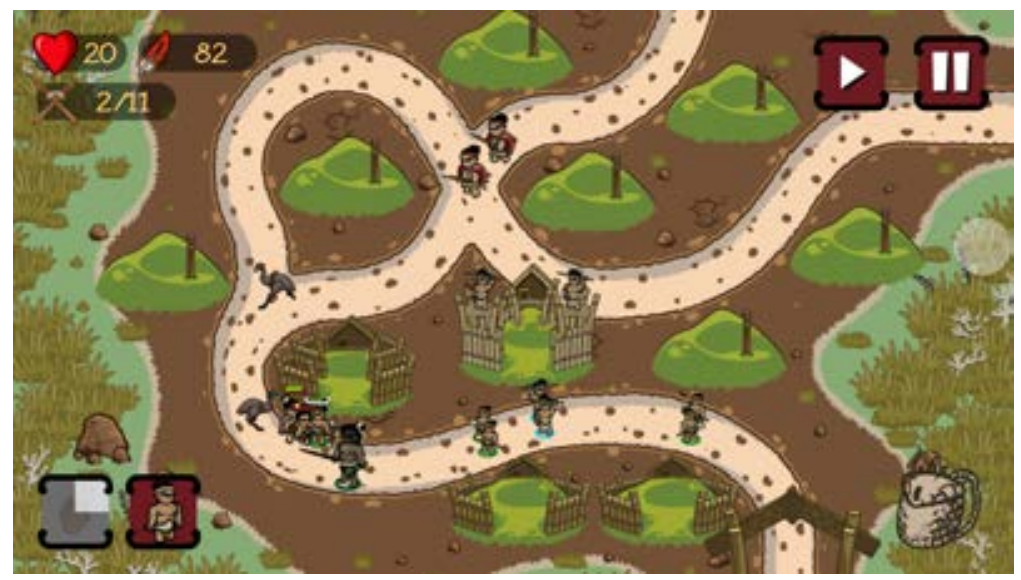

IWI WARFARE AND THE STRATEGY MECHANIC

Game design is a broad term that includes skillsets drawn from computer science, creative writing and graphic design to bring narrative, characters, gameplay, interfaces, and environments to life. Game mechanics are constructs of rules or methods designed for interaction with the game. ${ }^{29}$ As a 'tower defence' game, a sub-category of the 'strategy' genre, MPW draws on 'strategy' game mechanics. Like the popular real-time strategy game Clash of Clans (2012), MPW requires players to combine quick thinking with strategic planning and fast fingers to take down enemies. The goal is to set up defences by building $P \bar{a}$ (forts) on hills in village settings in order to train warriors to fight and throw spears and stones at enemy invaders.

The emphasis on strategy within gameplay mirrors the long history of iwi warfare that is rooted in the relationship to whenua (land). ${ }^{30}$ To begin the player sets up defences by strategically placing a combination of different $P \bar{a}$ sites and tools in their village, which in the right combination can serve to block, impede, attack or destroy enemies. This is in keeping with Walker's accounts of Māori defensive positions that "were so well chosen to take advantage of natural landforms, and reinforced with palisades, ring ditches and fighting stages, that they were difficult to take with weapons of the stone age." ${ }^{\prime 31}$ The game's strategy mechanics demonstrate how difficult it can be to employ skill, strategy and quick reflexes in a way that upholds the village. The game reproduces the basic strategies in traditional $P \bar{a}$ warfare which "relied on surprise attacks, feint assaults and mock retreats to lure the defenders out into the open." ${ }^{\prime 32}$ Despite its isometric $2 \mathrm{D}$ design the game is no easy feat and quick execution is a must. Walker reveals the preference in the conduct of war was to rely on subtlety instead of force, for example where the prowess of the enemy was respected and revered, and discovering his strength, neutralising it and attacking him at his weak point was a tactic relied on in war. ${ }^{33}$ The game conveys this in instances where an enemy can be approached differently, such as manu (birds) who must be whittled down with spears.

The strategy mechanic relates to tūrangawaewae (land as the basis of identity), whereby this sacred belief guides the practice of defending iwi boundary. ${ }^{34,35}$ Crossing the territorial boundaries of other iwi was fraught with danger not only because of past hostilities but because of dangers from local demons and kaitiaki (guardian spirits). The tapu (sacredness) of territorial boundary was contained in the markers of prominent physical features such as mountains, rivers, lakes, streams or distinctive land forms, which came to symbolise the chief and their tribe. ${ }^{36}$ In this sense MPW brings the concept of tangata whenua (people of the land) into the present through the competitive strategy game mechanic, and re-presents the ability and honour of defending one's place.

\section{TE REO MĀORI TO ENGLISH USER INTERFACE}

A key characteristic of the tower defence genre is the use of descriptive text instructions. These pieces of text describe the characters, Pā designs and tools available for the player to use or combine in order to reach victory, and occur in both English and te reo Māori. The game's user interface can switch between languages giving players the option to play as they see fit. While the text mainly occurs within instructions and title pages, they are central to playing the game and are further enhanced by a repetitive 'loop' mechanism that encourages learning through repetition.

The effects of colonisation for Māori has resulted in cultural discipline and language loss that was sanctioned by law to restrict, silence and suppress Māori ways of knowing. Currently te reo Māori is a minority language with about 157,000 speakers or 4.1 percent of the population, however data indicates its declining use among rangatahi (youth). ${ }^{37,38,39}$ Recent studies show that in order for te reo Māori to 


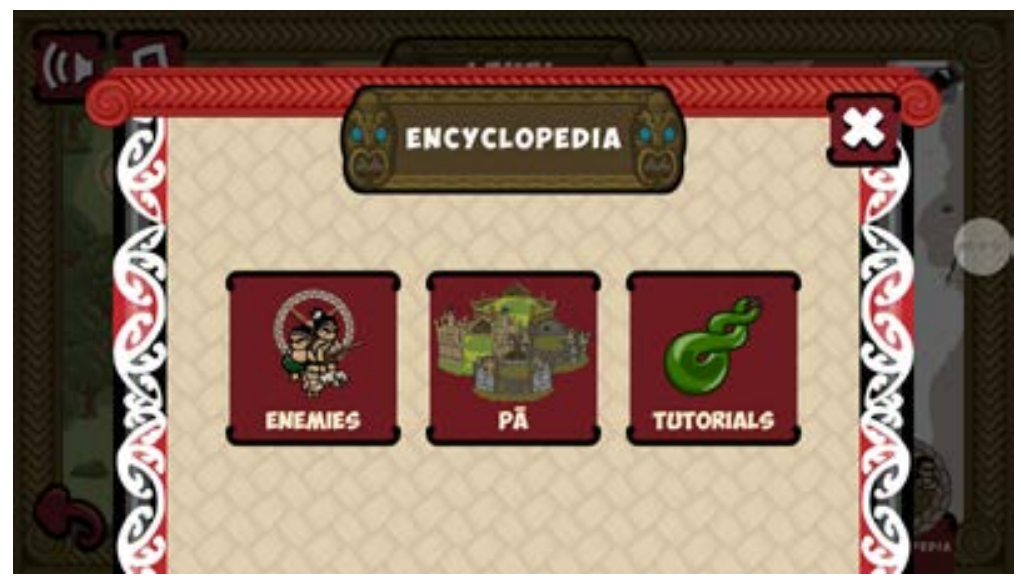

become part of rangatahi identity and worldview it must become valued or imbued with a sense of ownership. A language only spoken in certain domains fails to grow and adapt to a changing world, and in order for it to survive it must be used normally across a range of natural situations. ${ }^{40,41}$ As mobile technologies offer a hybrid space that is simultaneously composed of digital and material objects, the mobile game space is simultaneously play and everyday life. ${ }^{42}$ Activating te reo Māori within the mobile game space can counteract perceptions of a dormant language of the past.

Reclaiming a voice has therefore been about reconnecting and reordering those ways of knowing that were "submerged, hidden or driven underground. ${ }^{\prime \prime 43,44,45}$ The bilingual mechanism empowers te reo Māori revitalisation through freedom to engage with the language, symbolising freedom of choice obtained through greater access to both Māori and Pākehā knowledge forms. ${ }^{46,47}$

The bilingual mechanic can be compared to the dual playable character feature of the Cook Inlet Tribal Council (CITC) platform game Never Alone/Kisima Innitchuna (2014) where character switching between Nuna and Fox achieves tasks and highlights the traditional Iñupiat value of interdependence. Platformer game Adventures in Māoriland (2017) by artist, designer and educator Johnson Witehira (Ngāti Hinekura, Ngā Puhi, Ngāti Haua) also forces the player to switch between playing the role of an early Māori settler who must club seals for survival, to playing a Pākehā Missionary who must attack Māori with the Bible and convert them to Christianity. This mechanic is used to convey Witehira's bi-cultural, Māori-Pākehā identity. However within
Māoriland the player is not given the choice to opt out of the mechanic without dying, and conveys Witehira's wish for the player to experience both positions equally. ${ }^{48}$

\section{NGĀ ATUA AND TIPUA CHARACTER DESIGN}

Metia Interactive's approach to character design reveals the difficulty of representing matauranga Māori using the mobile game medium. The game depicts Ngā Atua (the pantheon of Māori gods) including Tāwhirimātea, Tāne Mahuta, Whiro and Rūaumoko, opting for a panMāori rendition of atua (gods). This is not new in art and design; artist Robyn Kahukiwa for example personified atua in her works Wāhine Toa: Women of Māori Myth (1984) and Taniwha (1986). ${ }^{49},{ }^{50}$ Certain design decisions do however reflect ongoing concerns with Indigenous content in games.

MPW incorporates a 'freemium' business model whereby atua can be purchased with 'Greenstone credit' to add extra killing power against enemies. This model mutually benefits the player while generating revenue for the developer. When atua are defeated a gravestone appears in their place, and this does not appear to capture the depth and richness of matauranga Māori in which atua are immanent, immortal, and highly revered. Tipua (demons) such as 'Ogre,' 'Traitor,' 'Healer,' 'Chief' and 'Spear Thrower,' are depicted somewhat generically and are unlocked to challenge the player as they progress through the levels. Perhaps their design could have benefited from iwi and hapū (sub-tribal) knowledge and specific tales of demons, for example Kopuwai (belly full of water, or water swallower), Te Ngārara Huarau (half-woman, half-lizard) and Ruruhikerepo (old witch-like woman). ${ }^{51}$ Variations of tohunga (priests) also occur according to different iwi, for example giants and flying men.

Oversimplified characters are familiar and accessible to a youthful game market but tread closely to Indigenous stereotypes often found in games. However, activating individual narratives has potential to enrich games more so than layering simplified characters on top of an existing format. Nihoniho has spoken about the difficulty of representing Māori content,

It's a lot of pressure, honestly as a Māori, because you not only have this thing about having to do it right, and I know if 


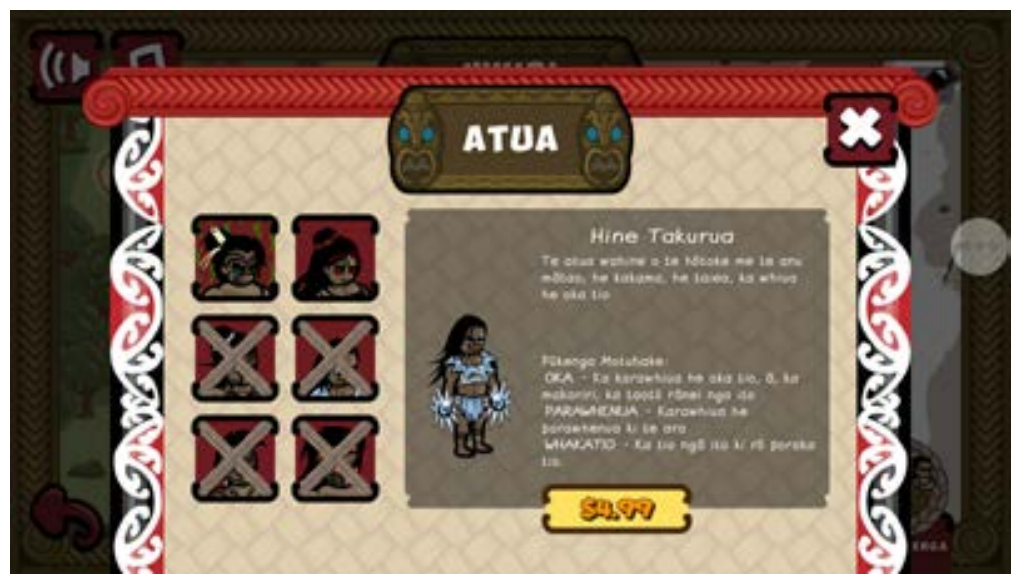

I don't, it will affect me directly. You know, not being able to tell the story right, or get the content right. So, it is an added layer of pressure when developing Māori stories or games for Māori in particular. ${ }^{52}$

Given the multiple interpretations of matauranga for different iwi, Nihoniho believes a degree of 'creative license' is required in addition to the constant reminder to be "aware and be careful of what you're dealing with in terms of content." 153 In this sense the game draws on remix and convergence cultures inherent to indie game development, where elements of design are replicated in the interest of generating activity and participation. ${ }^{54}$ This reflects the way in which Māori technologies, social and political systems continue to be adapted for a changing technological landscape. ${ }^{55}$

\section{UBIQUITY, MOBILITY AND IMMERSION}

The game's mobile medium itself challenges the view that Māori culture and peoples are static when, in reality, mobile devices are not a luxury but rather a fundamental service within the day-to-day lives of Māori communities. In Aotearoa rangatahi (Māori youth) are exceling in their use of mobiles and social media. ${ }^{56}$ Statistics NZ 'Household Use of Information and Communication Technology: 2012' reported that 75 percent of Mãori used social media compared with 61 percent of
Europeans. ${ }^{57}$ Additionally, more Māori were also downloading media and using mobile phones to access the Internet than Europeans. ${ }^{58}$

These statistics may be a reflection of the youthful Māori population, where the projected median age for Māori in 2021 is 26.8, compared with 39.8 for the country as a whole. ${ }^{59}$ This usage pattern is echoed globally where First Nations peoples in the US and Canada are an integral part of the "mobile explosion" due to the geographic isolation of many tribal communities. ${ }^{60}$

Mobile technology has begun to support the learning and sharing of customary knowledge, while also providing tools for social and economic renewal. ${ }^{61} \mathrm{~A}$ preference for mobile phones suggests that Indigenous-led mobile games and apps will continue to grow, ${ }^{62}$ and MPW takes advantage of this trend. Free to download for Android and smartphone means the game is accessible. The privacy afforded by personal mobile devices gives te reo Māori learners opportunities to learn at their own pace, lessening the instance of whakamā (embarrassment). This type of learning contrasts with institutional learning, which is external to whānau spaces and the everyday experience of Māori communities. Furthermore, the ubiquity of mobiles allows users to weave in and out of learning amidst their day-to-day activities, allowing users to become "authors of their own ontological ground." ${ }^{\prime \prime 3}$

The ubiquity and mobility of mobile devices allows for te reo Māori to be experienced within a hybrid space, activating it as a language of the present rather than a dormant language of the past. The affordable price and ability to connect anytime, anywhere, makes the mobile game a popular learning platform for rangatahi.

\section{CONCLUSION}

Māori Pā Wars brings the tradition of iwi warfare into the present through the immersive, immediate and interactive technology of the mobile game. It shares with players an ability to take greater control of their own history through immersion, play and the everyday, all without feeling like a history lesson. The game brings te reo Māori learning to the hybrid space of mobile phones, activating it as a language of the present rather than a dormant language of the past.

There are overlapping discourses and ways to approach game development. This essay offers a view of video games through the prism 
of kaupapa Māori. We can see how Indigenous 'authenticity' is fluid rather than fixed. This comes at a time when boundaries between local and global, reality and virtual, are disappearing rapidly. In the words of graphic artist Zak Waipara:

Culture is not static; it is part of a continuum, in the same way that whakapapa is. Think of an unending rope, where al the strands woven together provide strength. It recedes into the past, and proceeds into the future. If the rope is cut our connection to the past is lost. Where innovation is adopted, new strands must be woven into those that already exist, in such a way that the rope is strengthened, not weakened. ${ }^{64}$

\section{REFERENCES}

Ballara, Angela. Iwi: The Dynamics of Mãori Tribal Organisation From c.1769 to c.1945. Wellington: Victoria University Press, 1998

Brady, Fiona and Dyson, Laurel Evelyn. “Why Mobile?: Indigenous People and Mobile Technologies at the Edge," in Indigenous People and Mobile Technologies, edited by Laurel Evelyn Dyson Stephen Grant, Max Hendriks. New York; London: Routledge, 2016.

Dyson, Laurel Evelyn. “Framing the Indigenous Mobile Revolution," in Indigenous People and Mobile Technologies, edited by Laurel Evelyn Dyson, Stephen Grant, Max Hendriks. New York; London: Routledge, 2016

Farman, Jason. Mobile interface theory: Embodied Space and Locative Media. New York: Routledge, 2012.

Fuchs, Philippe and Pascal Guitton. Virtual Reality: Concepts and Technologies. Boca Raton: CRC Press, 2011.

Hillis, Ken. Digital Sensations: Space, Identity, and Embodiment in Virtual Reality Minneapolis: University of Minnesota Press, 1999.

Hokowhitu, Brendan and Vijay Devadas. Māori Media in Aotearoa New Zealand (Minneapolis: University of Minnesota Press, 2013.

Jenkins, Henry. Convergence Culture: Where Old and New Media Collide. New York: NYU Press, 2006
- "Relationality in Indigenous Food and Medicine Games." Resilience: A Journal of th Environmental Humanities, (2017): 191-200.

- "Native Representations in Video Games." Vimeo, 4 July 2011, https://vimeo. com/25991603.
Leaver, Tama and Michele Wilson. Social, Casual and Mobile Games: The Changing Gaming Landscape. New York: Bloomsbury Academic, 2016.

Lecky-Thompson, Guy W. Video Game Design Revealed. Boston: Course Technology, 2008.

Lilley, Spencer C. "Ko Aotearoa tenei: Indigenous Cultural and Intellectual Property Rights in Aotearoa New Zealand," in Indigenous Notions of Ownership and Libraries, Archives and Museums, edited by C. Callison, L. Roy, G. LeCheminant. Berlin: DeGruyter, 2016.

McIntosh, Tracey. "Marginalisation: A Case Study of Confinement," in Māori and Social Issues, edited by Tracey McIntosh, Malcolm Mulholland. Wellington: Huia, 2011

Mahuta, Dean. "Māori in Video Games - A Digital Identity." Kaharoa, 5(1), 2012.

Mancini, Huni. Transcription of "Te reo Games" NZGDA May \#AKLGAMEDEV Meetup, 23 May 2018.

- Transcription of "Indigenous Representation in Games" NZGDA Sep \#AKLGAMEDEV Meetup, 6 September 2017.

- "Mapping New Terrain: Indigenous Self-determination in App and Gam Development." MA thesis, University of Auckland, 2017.

Mead, Hirini Moko. Tikanga Māori: Living by Māori Values. Wellington: Huia, 2003.

Middleton, Suzanne. "Weaving the Fibres of the Future: How Māori Businesses are Embracing the Digital Age." Idealog, 62, May 2016.

Patterson, Christopher. "Heroes of the Open (Third) World: Killing as Pleasure in Ubisoft's

Far Cry Series." American Quarterly, 68(3),

September 2016.

Reed, A.W. and Ross Calman. Reed Book of Mãori Mythology. Auckland: Reed, 2004.

Ross, Luana. Inventing the Savage: The Social Construction of Native American Criminality. Austin: University of Texas Press, 1998.

Smith, Graham Hingangaroa. "The Development of Kaupapa Māori: Theory and Praxis." PhD thesis, University of Auckland, 1997.

Smith, Linda Tuhiwai. Decolonizing

Methodologies. London; New York: Zed Books, 2012
Starkey, Daniel. "No, this video game is not 'ecoterrorism." The Verge, 1 November 2017, https:// www.theverge.com/2017/11/1/16588166/gameecoterrorism-politics-thunderbird.

Statistics New Zealand. QuickStats about Māori: Census 2006. Wellington: Statistic New Zealand, 2007.

- Household Use of Information and Communication Technology: 2012. Wellington: Statistics New Zealand, 2013

- 2013 Census QuickStats about Mãori. Wellington: Statistics New Zealand, 2013.

Taffel, Sy. "Digital Places: Globalising Identity and Citizenship," in Türangawaewae: Identity \& Belonging in Aotearoa New Zealand. Auckland: Massey University Press, 2017.

Te Whata, Leah. "Newest te reo Māori Game App Māori Pa Wars Launches." Māori Television, 5 September 2017, https://www.maoritelevision. $\mathrm{com} /$ news/national/newest-te-reo-maori-gameapp-maori-pa-wars-launches.

UWIRE Text. "\#GamerGate." Academic OneFile, October 2014.

Waipara, Zak. "The Reckoning: Appropriation v Authenticity." The Sapling, 11 November

2017, https://www.thesapling.co.nz/singlepost/2017/11/03/The-Reckoning-Without-ourstories-we-are-incomplete.

Waitangi Tribunal. "Ko Aotearoa Tenei: A Report into Claims Concerning New Zealand Law and Policy Affecting Mãori Culture and Identity. Te Taumata Tuarua." Wellington: Legislation Direct 2011.

- "Waitangi Tribunal Bibliography 1975-2017: Part 1" Ministry of Justice, 14 February 2018. Walker, Ranginui. Ka Whawhai Tonu Mātou = Struggle Without End. Auckland: Penguin, 2004 Warren, Te Rina, Margaret Forster and Veronica Tawhai. "Tangata Whenua: Māori, Identity and Belonging," in Türangawaewae: Identity \& Belonging in Aotearoa New Zealand. Auckland: Massey University Press, 2017. 


\section{ENDNOTES}

1 Leah Te Whata, "Newest Te Reo Māori Game App Māori Pā Wars Launches" Māori Television, 5 September 2017, https://www. maoritelevision.com/news/national/newest te-reo-maori-game-app-maori-pa-warslaunches.

2 Jason Farman, Mobile Interface Theory: mbodied Space and Locative Media (New York: Routledge, 2012), 78.

3 Graham Hingangaroa Smith, "The

Development of Kaupapa Māori: Theory and Praxis" (PhD thesis, University of Auckland, 1997), I.

4 Hirini Moko Mead, Tikanga Māori: Living by

Smith, "The Development of Kaupapa Māori," 456.

6 The Treaty of Waitangi/Te Tiriti o Waitangi is the nation's founding document which was signed by more than forty chiefs and representatives of the British Crown on 6 February 1840.

7 Waitangi Tribunal, "Waitangi Tribunal Bibliography 1975-2017: Part 1" Ministry of Justice, 14 February 2018, 4.

8 Ivan Hugh Kawharu, Waitangi: Māori and Pakeha Perspectives of the Treaty of Waitang (Auckland: Oxford University Press, 1989), $319-320$

9 Spencer C. Lilley, "Ko Aotearoa Tenei: Indigenous Cultural and Intellectual Property Rights in Aotearoa New Zealand" Indigenous Notions of Ownership and Libraries, Archives and Museums (Berlin: DeGruyter, 2016), 110.

10 Brendan Hokowhitu and Vijay Devadas, Māori Media in Aotearoa New Zealand (Minneapolis: University of Minnesota Press, 2013), xxix.

11 Linda Tuhiwai Smith, Decolonizing Methodologies (London; New York: Zed Books, 2012), 140-142.

12 Elizabeth LaPensée, "Self-Determined Games" Companion to Media Studies and Digital Humanities (Abingdon: Routledge, 2017).

13 Smith, Decolonizing Methodologies, 142.

14 UWIRE Text, "\#GamerGate" Academic OneFile, 2 October 2014
15 Sarah Kaplan, "With \#GamerGate, the Video-Game Industry's Growing Pains Go Viral" Washington Post, 12 September 2014.

16 Daniel Starkey, "No, this video game is not eco-terrorism," The Verge, 1 November 2017.

17 Elizabeth LaPensée, "Transformations and Remembrances in the Digital Game We Sing for Healing" Transmotion, 3(1), 2017.

18 Zak Waipara, "The Reckoning: Appropriation v Authenticity" The Sapling, 3 November 2017.

19 Ibid.

20 Ibid.

21 Ibid.

22 Huni Mancini, Transcription of "Te reo Games" NZGDA May \#AKLGAMEDEV Meetup, 23 May 2018.

23 Dean Mahuta, "Māori in Video Games - a Digital Identity" Kaharoa, 5(1), 2012: 129-131.

24 Christopher Patterson, "Heroes of the Open (Third) World: Killing as Pleasure in Ubisoft's Far Cry Series" American Quarterly, 68(3), September 2016: 771.

25 Elizabeth LaPensée, "Native Representation in Video Games" Vimeo, 4 July 2011, https:// vimeo.com/25991603.

26 LaPensée, "Self-Determined Games."

27 LaPensée, "Native Representations in Video Games."

28 Huni Mancini, Transcription of "Indigenous Representation in Games" NZGDA Sep \#AKLGAMEDEV Meetup, 6 September 2017.

29 Guy W. Lecky-Thompson, Video Game Design Revealed (Boston: Course Technology, 2008) 21-51.

30 Ranginui Walker, Ka Whawhai Tonu Mātou = Struggle Without End (Auckland: Penguin, 2004), 70

31 Ibid., 71

32 Ibid.

33 Ibid., 71-72.

34 Ibid., 135.

35 Te Rina Warren, Margaret Forster and Veronica Tawhai, "Tangata Whenua: Māori, Identity and Belonging" Türangawaewae: Identity \& Belonging in Aotearoa New Zealand (Auckland: Massey University Press, 2017), 5354.
36 Walker, Ka Whawhai Tonu Mātou, 70

37 Statistics New Zealand, QuickStats about Mãori: Census 2006 (Wellington: Statistics New Zealand, 2007).

38 Statistics New Zealand, Household Use of Information and Communication Technology: 2012 (Wellington: Statistics New Zealand, 2013).39 Te Taka Keegan and Danie Cunliffe, "Young People, Technology and the Future of te Reo Mãori" The Value of the Mãori Language $=$ Te hua $\circ$ te reo Māori (Wellington: Huia, 2014), 385.

40 Ibid., 386.

41 lbid., 396.

42 Jason Farman, Mobile Interface Theory: Embodied Space and Locative Media (New York: Routledge, 2012), 78-79.

43 Smith, Decolonizing Methodologies, 134.

44 Luana Ross, Inventing the Savage: The Socia Construction of Native American Criminality (Austin: University of Texas Press, 1998), 3.

45 Tracey Mclntosh, "Marginalisation: A Case Study of Confinement" Māori and Socia Issues (Wellington: Huia, 2011), 263.

46 Smith, "The Development of Kaupapa Māori,"

47 LaPensée, "Self-Determined Games."

48 Mancini, "Indigenous Representation in Games."

49 Robyn Kahukiwa, Wāhine Toa: Women of Māori Myth (Auckland: Collins, 1984).

50 Robyn Kahukiwa, Taniwha (Auckland: Puffin 1986).

51 A.W. Reed and Ross Calman, Reed Book of Māori Mythology (Auckland: Reed, 2004), 230 258

52 Mancini, "Te reo Games."
53 Mancini, "Indigenous Representation in Games."

54 Henry Jenkins, Convergence Culture (New York: NYU Press, 2006).

55 Angela Ballara, Iwi: The Dynamics of Māori Tribal Organisation From c.1769 to c.1945 (Wellington: Victoria University Press, 1998), 21.

56 Sy Taffel, "Digital Places: Globalising Identity and Citizenship" Tūrangawaewae: Identity \& Belonging in Aotearoa New Zealand (Auckland: Massey University Press, 2017), $188 ; 195$.

57 Statistics New Zealand, Household Use of Information and Communication Technology: 2012 (Wellington: Statistics New Zealand, 2013).

58 Suzanne Middleton, "Weaving the Fibres of the Future: How Mãori Businesses are Embracing the Digital Age" Idealog, 62, May 2016: 2

59 lbid.

60 Laurel Evelyn Dyson, "Framing the Indigenous Mobile Revolution" Indigenous People and Mobile Technologies (New York; London Routledge, 2016), 6

61 Ibid., 1

62 Fiona Brady and Laurel Evelyn Dyson, "Why Mobile?: Indigenous People and Mobile Technologies at the Edge" Indigenous People and Mobile Technologies (New York; London: Routledge, 2016), 25.

63 Ken Hillis, Digital Sensations: Space, Identity and Embodiment in Virtual Reality (Minneapolis: University of Minnesota Press, 1999), xxix

64 Waipara, "The Reckoning." 